\title{
Performance Evaluation of BRRI Power Weeder for Low Land Rice (Oryza sativa L.) Cultivation
}

\author{
A.K.M. Saiful Islam ${ }^{1}$, M.T. Islam ${ }^{2}$, M. Sh. Islam ${ }^{3}$, A.K.M. Lutfor Rahman ${ }^{4}$ \\ and M.A. Rahman ${ }^{1}$ \\ ${ }^{1}$ Farm Machinery and Postharvest Technology Division, ${ }^{3}$ Agronomy Division, \\ Bangladesh Rice Research Institute, Gazipur; ${ }^{2}$ Post Graduate Student, Bangladesh Agricultural \\ University, Mymensingh; ${ }^{4}$ Assistant Commissioner, Office of the Deputy Commissioner, Cox's Bazar \\ *Corresponding author and Email: akmsaifulislam68@gmail.com
}

Received: 6 November 2016

Accepted: 12 June 2017

\begin{abstract}
Mechanical intervention in crop production is increasing rapidly in Bangladesh. Researchers are finding ways to manage weeds in rice field using suitable mechanical devices instead of conventional hand weeding. A study was conducted to evaluate the field performance of BRRI (Bangladesh Rice Research Institute) power weeder compared to BRRI weeder and hand weeding in the farmers' field at Rashidpur in Mithapukur upazila under Rangpur district during boro season of 2014-15. Three treatments: $\mathrm{T}_{1}=\mathrm{BRRI}$ weeder $(\mathrm{BW}), \mathrm{T}_{2}=\mathrm{BRRI}$ power weeder $(\mathrm{BPW})$ and $\mathrm{T}_{3}=$ Hand weeding $(\mathrm{HW})$ were used in the experiment. The experiment was carried out in a randomized complete block design (RCBD) and replicated in four farmers' plots. Rice variety BRRI dhan28 was selected for the experiment. The effective field capacity of BW and BPW was found to be 0.06 and $0.09 \mathrm{ha} \mathrm{hr}^{-1}$, respectively. The weeding efficiency was the highest in HW (92\%), followed by BPW (78\%) and BW $(73 \%)$. It was found that BW damaged the lowest number of plants $(9 \%)$ compared to BPW $(11 \%)$ during weeding operation, although the damaged plants recovered after a few days. BW and BPW reduced 74 and $85 \%$ of labor requirement in weeding operation compared to HW. The highest weeding cost was involved in HW (Tk. $4287 \mathrm{ha}^{-1}$ ) compared to BW (Tk. $1103 \mathrm{ha}^{-1}$ ) and BPW (Tk. 950ha ${ }^{-1}$ ). Weed control methods exerted insignificant effect on grain yield. BRRI power weeder and BRRI weeder reduced weeding cost, enhanced weed control and improved the labor efficiency without sacrificing grain yield. The highest BCR was obtained in BPW (1.22) followed by BW (1.16) and HW (1.11). BRRI power weeder and BRRI weeder appeared to be economic, easy and also environmentally safe weed control device in low land rice cultivation.
\end{abstract}

Keywords: Weeder, field capacity, weeding efficiency, labor, yield, benefit-cost ratio.

\section{Introduction}

Weeding is one of the most important farm operations in crop production system. Chinnusamy et al. (2000) reported that maintaining a weed free period for up to 45 days after transplanting was essential to augment the yield of medium duration rice (Oryza sativa L.). In rain-fed lowland rice, 30-60 days after sowing period was considered as critical period for crop weed competition to avoid grain yield losses (Moorthy and Saha, 2005). Singh et al. (2002) observed that maintaining weed free condition till maturity gave significantly higher grain yield 
due to more panicles $\mathrm{m}^{-2}$ and lower density and dry weight of weeds. Crop yield losses due to weeds mainly depend upon their intensity as well as on type of weed flora. There is a linear correlation between yield loss and population of weeds. However, above a certain population limit, yield reduction becomes nearly constant due to self-competition among weed plants. Manual weeding is very effective but it is tedious, time consuming and expensive in large scale cultivation. Continuous rains in rainy season and unavailability of man power make manual weeding difficult (Puniya et al., 2007). Pal et al. (2009) found that rice having hand weeding at 20 and 40 DAT gave the highest grain yield of $5.08 \mathrm{t} \mathrm{ha}^{-1}$ in the Gangetic alluvial soil, mostly because of having little scope to flourish weeds and to compete with the crop preferably at the critical stage of crop weed competition. Dutta et al. (2005) reported that hand weeding of rice twice at 21 and 42 DAS (days after sowing) contributed to the highest weed control efficiency and increased grain and straw yield of rice crop. The weed control cost was maximum for hand weeding (two hand weeding at 30 and 45 DAT) and the lowest for chemical weed management (Hasanuzzaman et al., 2007). Uphoff (2002) reported that the mechanical hand weeder pruned some of the upper roots and encouraged deeper root growth. Randriamiharisoa (2002) noticed that the mechanical weeding using rotating hoe with small toothed wheels increased the soil pores so that roots and microbes could more easily gain access to oxygen and also significantly increase the tiller production.

As the time period available for weeding is limited, improved mechanical weeders are to be used to complete the weeding operation in due time at minimum cost. There is an increasing interest in the use of mechanical weeder because of concern over environmental degradation due to herbicide use and a growing demand for organic food. Agricultural sector requires nonchemical weed control methods to ensure food safety and pollution free environment. Mechanical weeder can control weeds in a way that meets consumer and environmental demands and pollution free environment. Mechanical weed control methods ensure the safeguard against the soil and water pollution also. Most of the farmers of Bangladesh control weed in rice field by hand weeding. Mechanical weed control not only uproots the weed between the crop rows but also keeps the soil surface loose, ensuring better soil aeration and water intake capacity. Recently, BRRI power weeder was developed to control the low land weed in rice culture. BRRI power weeder is equipped with three rotors to weed out three rows in single pass operation and powered by petrol engine. This machine needs thorough investigation in the farmers' field. Therefore, the present study was undertaken to evaluate the field performance of BRRI power weeder, estimate the yield performance of rice due to weed control by the weeders and compare the cost efficiency of mechanical weeding over traditional hand weeding.

\section{Materials and Methods}

This experiment was conducted in the farmers' field, Rashidpur, Mithapukur, Rangpur during 14 December 2014 to 02 May 2015 (seeding to harvesting). The treatments sequences were $T_{1}=$ weeding with BRRI weeder $(\mathrm{BW})$ at $25 \mathrm{DAT} ; \mathrm{T}_{2}$ = weeding with BRRI power weeder $(\mathrm{BPW})$ at $25 \mathrm{DAT}$ and $\mathrm{T}_{3}=$ weeding by hand $(\mathrm{HW})$ at 25 DAT and 55 DAT. The experiment was carried out in randomized complete block design (RCBD) and replicated in four plots. Rice variety BRRIdhan28 was transplanted manually with a spacing of $20 \times 20 \mathrm{~cm}$. The field was prepared using common tillage practice, which is first plowing (primary tillage) once, followed puddling (secondary tillage) twice and leveling using two-wheel tractor under the flooding conditions. Forty-three days old seedlings were uprooted carefully from the nursery field and transplanted on18 January, 2015. Fertilizer was applied as per recommendation set by BRRI. The human labor involved in each operation was recorded through field measurements. Irrigation water was applied time to time as when required for the crop. 


\subsection{Cultural practices (weeding)}

Weeding was done manually by hand twice at 25 days after transplanting (DAT) and 55 DAT and machine weeding once at 25 DAT (Photo 1). After that no other weeding operation was done up to harvest. During weeding different weed species grown in the experimental plot were identified and counted species-wise.

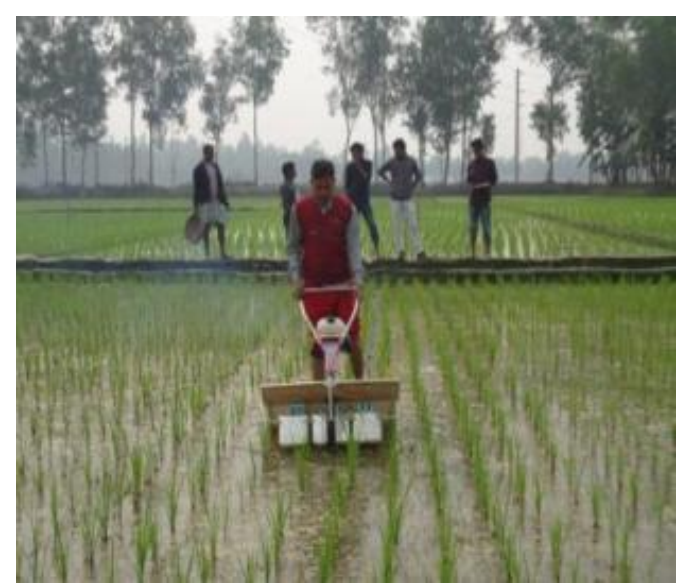

a. BRRI power weeder

\subsection{Weed species}

Data on weed density were collected from each plot at vegetative stage of the rice plants by using $0.5 \times 0.5 \mathrm{~m}$ quadrate as per method described by Cruz et al. (1986). The quadrate was placed in three spots at random. The weeds within the quadrate were counted species-wise and converted to number $\mathrm{m}^{-2}$ multiplying by four.

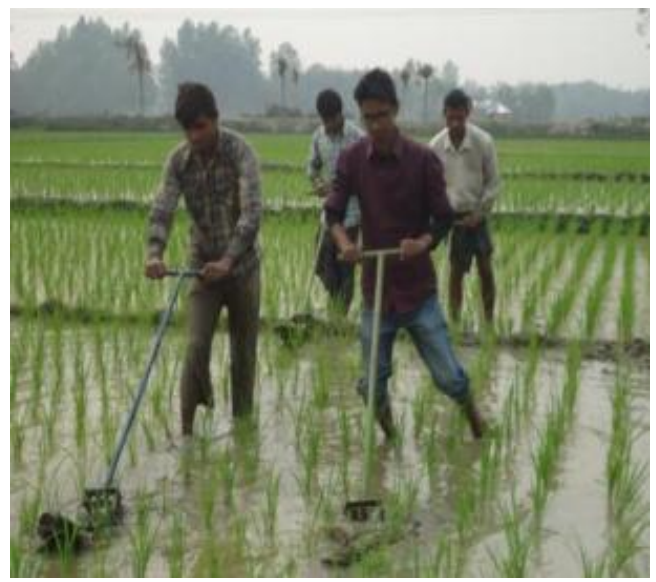

b. BRRI weeder

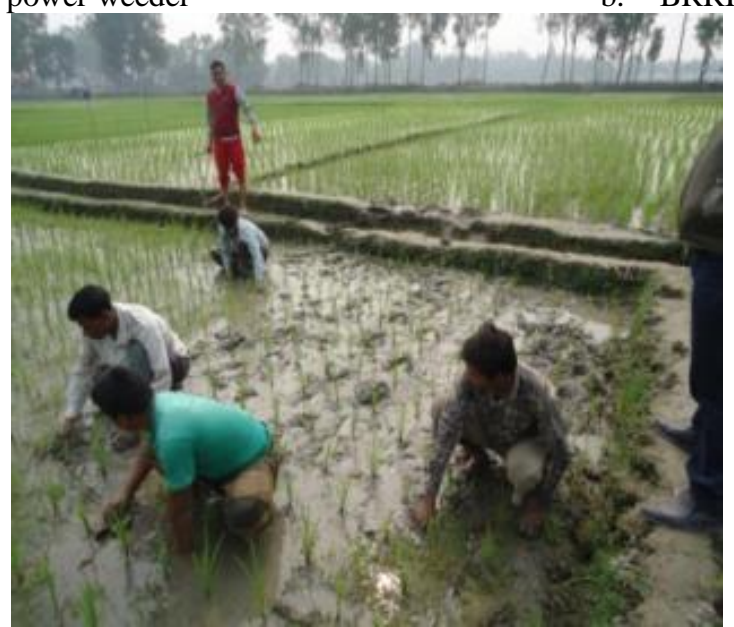

c. Hand weeding

Photo 1. Weed management options 


\subsection{Field capacity}

It is the ratio of actual average rate of field coverage by the machine to the total time during operation (Hunt, 1995). Therefore,

$C=\frac{A}{T}$

Where,

$\mathrm{C}=$ Actual field capacity, ha $\mathrm{hr}^{-1}$

$\mathrm{A}=$ Total transplanted area, ha

$\mathrm{T}=$ Total operating time required for transplanting, hr

\subsection{Weeding efficiency}

To determine the weeding efficiency in three places of each plot bamboo frame of $1 \mathrm{~m} \times 1 \mathrm{~m}$ was thrown in the field randomly and the number of weeds was counted. The weeding efficiency was computed by using the following equation:

Weeding efficiency, $\sum=\frac{w_{1}-w 2}{w} \times 100 \ldots \ldots \ldots . . .(2)$

Where,

$\mathrm{W}_{1}=$ number of weeds before weeding

$\mathrm{W}_{2}=$ number of weeds after weeding

$\sum=$ weeding efficiency

\subsection{Tiller damaged}

After weeding operation, bamboo frame of 0.50 $\times 0.50 \mathrm{~m}$ was thrown in three places of each plot randomly and the number of damaged plant in the frame was counted (Tewari et al., 1993). The percent of breakage of rice tiller was computed by using the following equation:

$\mathrm{DP}=\frac{\mathrm{Q} 1}{\mathrm{Q} 2} \times 100$

Where,

$\mathrm{DP}=$ Damaged tillers $(\%)$

$\mathrm{Q}_{1}=$ Number of tillers broken in the row after weeding operation

$\mathrm{Q}_{2}=$ Total number of plants in the row

\subsection{Yield and yield contributing characters}

Grain yield was recorded from pre-selected 10 $\mathrm{m}^{2}$ area and adjusted to moisture content of $14 \%$. The plant height was measured from the base of the hill to the tip of the longest panicle. Twelve hills from each of the plots were collected randomly. The number of effective and non- effective tillers from each hill was noted. For computing, aboveground biomass and yield contributing characters, 4 hills were collected from the outside of the selected area. The dry weight of straw was determined after ovendrying at $70^{\circ} \mathrm{C}$ to constant weight. Panicle number of each hill was counted to determine the panicle number $\mathrm{m}^{-2}$. Plant samples were separated into straw and panicles. Panicles were hand-threshed and the filled spikelets were separated from unfilled spikelets. Border areas of all sides of the plot were excluded to avoid border effects.

\subsection{Economic and statistical analysis}

In order to estimate the production cost, the data on working speed, total time and labor inputs by the weeder, manual worker and materials inputs to complete the operations were recorded. Fixed cost and variable cost of the weeder was calculated using the method mentioned in Hunt (1995). Rental charge of the machines was also included in the cost estimation. Price of the produce was collected from the local markets to compute total production cost, gross return, gross margin and benefit-cost ratio. Data were analyzed by using statistical software Statistix 9.0. Means were compared with least significant difference (LSD) test.

\section{Results and Discussion}

\subsection{Weed infestation}

Eight different weed species belonging to three families of which 4 annual and 4 perennial were found in the experimental plot. Among eight weed species, one was sedge, one was broad leaf and six were grasses. The most predominant weed species in the experimental plots was Chesra (Scripus maritimus), other important weeds were Anguli (Digitaria sanguinalis (L).; Scop), Durba (Cynodon dactylon (L). pers) and Chela ghash (Rottboellia protensha Hack.). The Khudeshama (Echinochloa colonum (L). Beauv) was the least abundant weed species in the experimental plot. Some upland weeds observed in the fields due to dry condition of land. 


\subsection{Field capacity}

The field capacity of BW (0.06 ha $\left.\mathrm{hr}^{-1}\right)$ was higher than BPW (0.09 ha $\left.\mathrm{hr}^{-1}\right)$ (Fig. 1). Operator's skill influenced the performance of weeder. At the end of each pass, operator lifted the machine, placed the machine in another new rows and started operation. This increased the turning time loss which reduced the field capacity of the BPW. Alizadeh (2011) obtained the similar field capacity of power weeder $(0.08$ ha $\mathrm{hr}^{-1}$ ). Remesan et al. (2007) also observed that the effective field capacity of rotary weeder was $0.02 \mathrm{ha} \mathrm{hr}^{-1}$ which was lower than BW.

\subsection{Labor requirement in weeding operation} Labor requirement in $\mathrm{HW}, \mathrm{BW}$ and $\mathrm{BPW}$ were obtained 86, 22 and 13 man-hr ha ${ }^{-1}$ (Fig. 2). Hand weeding appeared as labor intensive works in rice production. BW and BPW reduced by 74 and $85 \%$ labor requirement in weeding operation compared to HW. Alizadeh (2011) mentioned that the labor input in mechanical weeder was obtained 36 man-hr ha ${ }^{-1}$ whereas 112 man-hr ha ${ }^{-1}$ in hand weeding which was higher than the present finding. This might be due to the variation in weed density and type of weed.

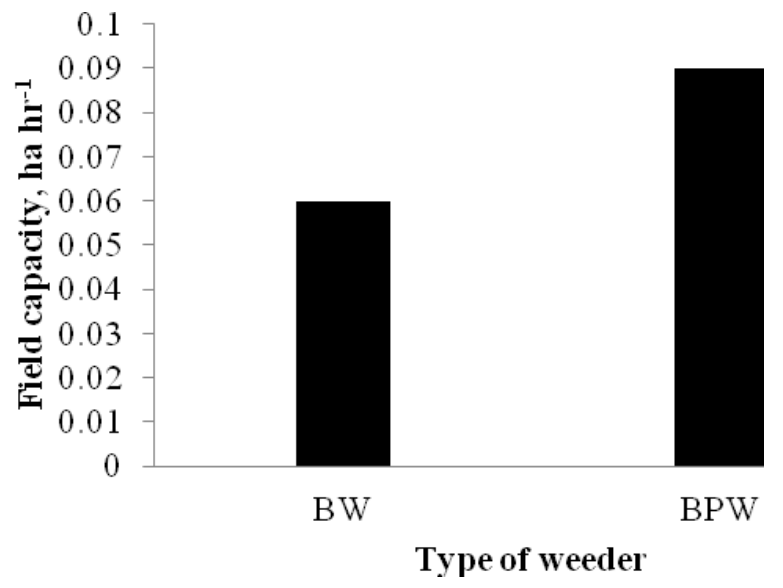

Figure 1. Field capacity of weeders

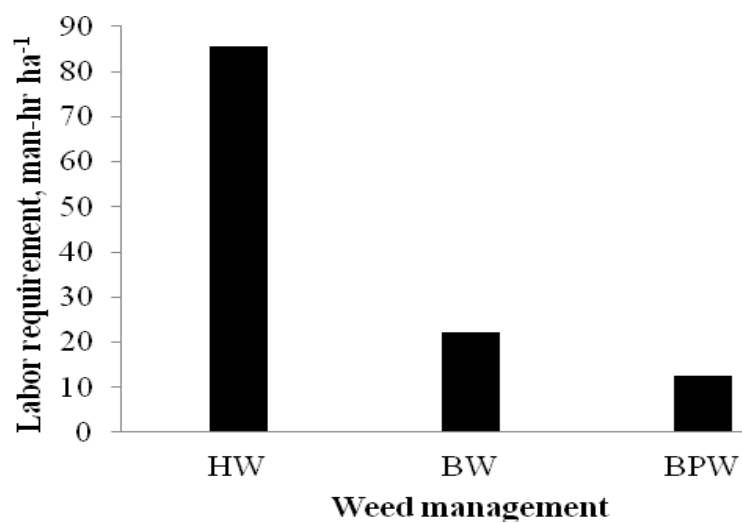

Figure 2. Labor requirement in different weed managements 


\subsection{Weeding efficiency}

Means comparison for weeding efficiency in the experimental treatments is demonstrated in Table 1. BW and BPW worked in the top 2-3 cm layer where most weeds were grown. The highest weeding efficiency was obtained in HW (92\%) followed by BPW (78\%) and BW (73\%). Dutta et al. (2005) reported that hand weeding twice at 21 and 42 DAS recorded the highest weeding efficiency. The results showed that for each type of weeding method, the weeding efficiency in BPW was more than BW. This could be attributed to utilized active rotors mechanism in the power weeder. It means the engine would provide the required power for rotor caused better blades grips with soil, resulting in higher weeding efficiency of the weeder. Generally, weeding efficiency depends on the weeder type, weed species and the weeding time. If weeding is delayed, the weeding efficiency will be decreased for excessive growth of weeds in soil and improper involvement of machine blades in soil depth. Alizadeh (2011) tested the weeding efficiency of two types of weeder in low land rice cultivation in Iran and found that weed efficiency of power weeder $(84 \%)$ was higher than the rotary weeder (73\%). Ramesan et al. (2007) reported that the weeding efficiency of rotary weeder was around to be $72 \%$, respectively. Subudhi (2004) reported that the efficiency of different types of hand operated weeder is between 76 to $91 \%$. These findings are consistent to the results of the present experiment.

\subsection{Tiller damaged}

Figure 3 showed the means comparison for damaged plants in the experimental treatments. Results indicated that the least percentage of damaged plants $(9 \%)$ obtained in BW. The BPW caused higher damaged plant $(11 \%)$, although it had high efficiency rather than BW. The movements of weeder machines encounters difficulties in BPW plot because of the distribution pattern and shading of plant over spaces between the rows and percentage of damaged plant will be consequently occurred. Moreover, the weeder moved swiftly between the rows caused more damages of plants through weeding. Alizadeh (2011) observed the lowest damage of plants in rotary $(4.26 \%)$ and power weeded $(4.03 \%)$ plot which may be due to erect behavior of the hybrid rice variety than that of inbreed BRRIdhan 28 and weeder moves easily between the rows caused fewer damages of plants through weeding.

\subsection{Yield and yield contributing character}

Data on yield and yield contributing character were statistically analyzed and presented in Table 2. Weed management had significant effect on other parameters whereas, no effect on grain yield and yield contributing characters.

Table 1. Effect of weed management on weed population and weeding efficiency

\begin{tabular}{|c|c|c|c|c|c|}
\hline \multirow[b]{2}{*}{ Treatment } & \multicolumn{5}{|c|}{ Weed population } \\
\hline & $\begin{array}{l}\text { Weeds before } \\
\text { weeding, no. } \\
\mathrm{m}^{-2}\end{array}$ & 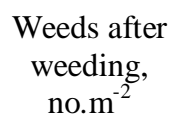 & $\begin{array}{c}\text { Weeding } \\
\text { efficiency,\% }\end{array}$ & $\begin{array}{c}\text { Weeds after } 3 \\
\text { days of } \\
\text { weeding, no. } \mathrm{m}^{-2}\end{array}$ & $\begin{array}{l}\text { Weeds after } 10 \\
\text { days of weeding, } \\
\text { no. } \mathrm{m}^{-2}\end{array}$ \\
\hline $\mathrm{HW}$ & 308 & 25 & 92 & 149 & 165 \\
\hline BW & 334 & 75 & 76 & 122 & 109 \\
\hline BPW & 217 & 75 & 78 & 98 & 107 \\
\hline
\end{tabular}




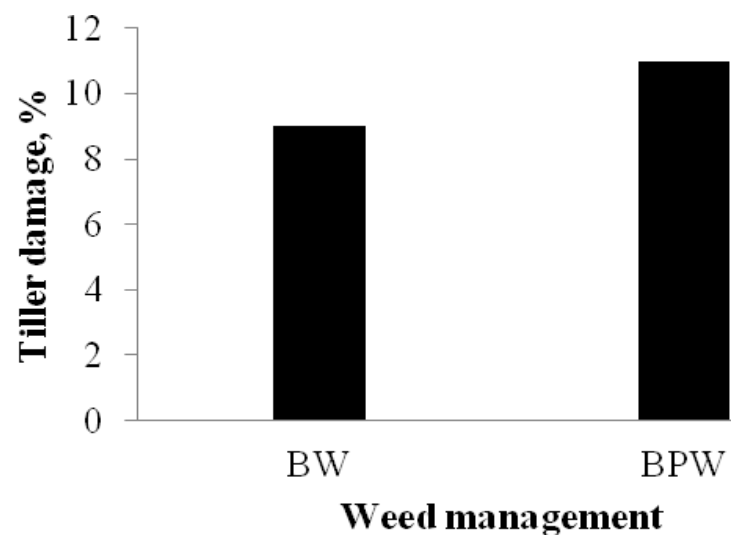

Figure 3. Tiller damage during weeding operation

Table 2. Yield and yield contribution characters as influenced by different weed management options, boro 2015-16

\begin{tabular}{lcccc}
\hline Treatments & Panicle $\left(\right.$ no. $\left.\mathrm{m}^{-2}\right)$ & 1000-grain wt. (g) & $\begin{array}{c}\text { Grain yield } \\
\left(\mathrm{t} \mathrm{ha}^{-1}\right)\end{array}$ & Sterility (\%) \\
\hline BW & 264 & 21.04 & 5.33 & 26.35 \\
BPW & 240 & 19.28 & 5.71 & 24.28 \\
HW & 233 & 20.51 & 5.29 & 31.72 \\
\hline CV $(\%)$ & 18.76 & 7.41 & 6.39 & 31.35 \\
$\operatorname{LSD}_{(0.05)}$ & $\mathrm{NS}$ & $\mathrm{NS}$ & $\mathrm{NS}$ & $\mathrm{NS}$ \\
\hline
\end{tabular}

\subsection{Weeding cost}

Weeding costs of different weeding methods are shown in Fig. 4. In BPW and BW, the cost of machine operation was the sum of fixed and variable costs. In $\mathrm{HW}$, the cost of operation is just related to the labor cost. Weeding cost of HW, BW and BPW was obtained Tk. 4287, 1103 and 950 per hectare. BW and BPW reduced 74 and $78 \%$ weeding cost compared to HW. Other researchers also reported that weeding cost decreased in the mechanized methods over hand weeding (Alizadeh, 2011; Goel et al., 2008 and Remesan et al., 2007).
3.8 Effect of weed control methods on total cost, gross return and net return

Total production cost including all the costs shown in Table 3. The gross return was calculated based on the existing market price of paddy and straw. Production cost per hectare showed the highest in HW. The gross returns and net return was obtained the highest in BPW followed by $\mathrm{BW}$ and $\mathrm{HW}$, respectively. The BPW showed the highest BCR (1.22) followed by BW (1.16) and HW (1.11) due to less labor requirement in weeding operation. 


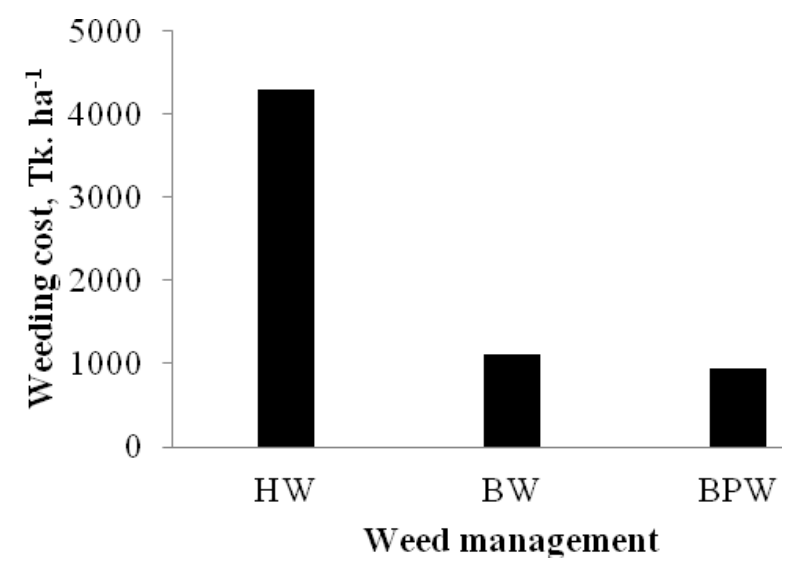

Figure 4. Weeding cost in different weed management

Table 3. Gross return, net return and benefit cost ratio (BCR)as calculated for weed management with BRRI weeder, BRRI power weeder and by hand weeding

\begin{tabular}{|c|c|c|c|c|c|c|}
\hline Treatments & 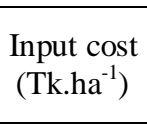 & $\begin{array}{l}\text { Return } \\
\text { from grain } \\
\left(\mathrm{Tk} . \mathrm{ha}^{-1}\right)\end{array}$ & $\begin{array}{c}\text { Return } \\
\text { from straw } \\
\left(\mathrm{Tk} . \mathrm{ha}^{-1}\right)\end{array}$ & $\begin{array}{c}\text { Gross } \\
\text { return }(\mathrm{Tk} . \\
\left.\mathrm{ha}^{-1}\right)\end{array}$ & $\begin{array}{c}\text { Net } \\
\text { return } \\
\left(\mathrm{Tk} . \mathrm{ha}^{-1}\right)\end{array}$ & $\begin{array}{c}\text { Benefit } \\
\text { Cost Ratio } \\
(\mathrm{BCR})\end{array}$ \\
\hline & $\mathrm{A}$ & B & $\mathrm{C}$ & $\mathrm{D}=\mathrm{B}+\mathrm{C}$ & $E$ & $\mathrm{~F}$ \\
\hline BW & 84,686 & 86,450 & 11,970 & 98,420 & 13,734 & 1.16 \\
\hline BPW & 86,789 & 92,788 & 12,840 & $1,05,636$ & 18,847 & 1.22 \\
\hline HW & 88,961 & 85,963 & 11,895 & 97,866 & 9,905 & 1.11 \\
\hline
\end{tabular}

\section{Conclusions}

BRRI power weeder was found to have the highest effective field capacity. The labor requirement for weed management with BRRI weeder and BRRI power weeder was reduced by 74 and $85 \%$, respectively compared to hand weeding method. Weeding cost in BRRI weeder and BRRI power weeder was decreased by 74 and $78 \%$, respectively compared to hand weeding method. Therefore, BRRI power weeder was more effective and economic in weed management under low land rice cultivation though it created some tiller damage. However, the performance of the power weeder should be compared with weed management by the application of herbicides.

\section{Acknowledgement}

The authors acknowledge the funding of the Bill and Melinda Gates Foundation through the CIMMYT implemented CSISA-II project especially Mr. Timothy Russel, Chief of Party, CSISA-BD for the implementation of the research activity. The authors deeply express their gratitude to BRRI authority for providing research support and facilities.

\section{References}

Alizadeh, M. R. 2011. Field performance evaluation of mechanical weeders in the paddy field. Scientific Research and Essays, 6(25):5427-5434. 
Chinnusamy, C., Kandasamy, O.S., Sathyamoorthy, K. And Chandrasekar, C.N. 2000. Critical period of crop weed competition in lowland rice ecosystems. In: Proceedings of State level seminar on Integrated Weed Management in new millennium, Ratnagiri, Maharastra. 27-28 Feb. 2000.

Cruz, E. D., Moody K. and Mamos, M. B. 1986: Reducing variability in sampling weeds in upland rice (Oryza sativa). Philippine Journal of Weed Science, 13:56-67.

Dutta, A., Patra, B.C., Jana, P. and Mandal, N. 2005. Effect of fertility levels and weed management practices on growth, yield attributes and yield of direct seeded rice in the rainfed and lateritic belt of West Bengal. p. 69. In: First International weed science seminar on innovative approaches for eco safety weed management, Kolkata, India. 21-24 Jan. 2005.

Goel, A. K., Behera, D., Behera, B. K., Mohanty, S. K. and Nanda, S. K. 2008. Development and ergonomic evaluation of manually operated weeder for dry land crops. The CIGRE Journal, Manuscript PM 08009, 10:1-11.

Hasanuzzaman, M., Nahar, K. andKarim, M.R. 2007. Effectiveness of different weed control methods on the performance of transplanted rice. Pakistan Journal of Weed Science Research, 13(1-2):17-25.

Hunt, D. 1995. Farm Power and Machinery Management, Cost determination, $9^{\text {th }}$ edition, Iowa State University press, USA.

Moorthy, B.T.S. and Saha, S. 2005. Studies on crop weed competition in rainfed direct seeded lowland rice (Oryza sativa L.). Indian Journal of Weed Science, 40(34):112-116.

Pal, D., Ghosh, R.K., Sounda, G., Dolai, A.K., Pramanick, M. and Mallick, S. 2009. Bio efficacy of some promising herbicides in transplanted kharif rice and their influence on soil microflora. Indian Agriculture, 53(3\&4):193-198.

Puniya, R., Pandey, P.C., Bisht, P.S. and Singh, D.K. 2007. Nutrient uptake by crop and weeds as influenced by Trisulfuron, Trisulfuron + Pretilachlor and Bensulfuron-methyl in transplanted rice (Oryza sativa L.). Indian Journal of Weed Science, 39(3\&4):239-240.

Randriamiharisoa, 2002. Research results on the System of Rice Intensification in Madagascar. In Proc. Intl. Conf. on Assessments of the System of Rice Intensification (SRI), Sanya, China. 1-4 April, 2002.

Remesan, R., Roopesh, M. S., Remya, N. And Preman, P. S. 2007. Wet land weeding- A comprehensive comparative study from south India. The CIGR E-journal. Manuscript PM 07011, 9:1-21.

Singh, R.K., Sharma, S.N. Singh, R. and Pandey, M.D. 2002. Efficacy of method of planting and weed control measures on nutrient removal of rice (Oryza sativa L.) and associated weeds. Crop Research, 24(3):425-429.

Subudhi, C. R. 2004. Evaluation of weeding devices for upland rice in the eastern Ghat of Orissa, India. International Rice Research Notes (IRRN), 29(1):79- 80.

Tewari, V. K., Datta, R. K. and Murthy, A. S. 1993. Field performance of weeding blades of a manually operated push-pull weeder. Journal of Agriculture Engineering Research, 55(2):129-141.

Uphoff, N. 2002. System of rice intensification (SRI) for enhancing the productivity of land, labor and water. Journal of Agriculture Resource Management, 1:4349. 